\title{
Beetles in polypores of the Moscow region: checklist and ecological notes
}

\author{
Nikolay B. Nikitsky \& Dmitry S. Schigel*
}

Nikitsky, N. B. \& Schigel, D. S. 2004: Beetles in polypores of the Moscow region, Russia: checklist and ecological notes. - Entomol. Fennica 15: 6-22.

Polypore inhabiting beetles in the Moscow region were studied. Sixty-one polypore species harboured 261 species of beetles (174 species coming to polypores as imago, 87 species developing in polypores at larval stage). The highest number of species was found in polypores growing on deciduous trees: Fomes fomentarius (102 beetle species), Polyporus squamosus (94 species), Laetiporus sulphureus (81 species) and Piptoporus betulinus (62 species). Imaginal species diversity is much higher than larval, although the later can be more abundant. Ennearthron cornutum (found on 20 species of polypores) and Cis comptus (16 species) occurred in the largest number of fungal species.

N. B. Nikitsky, Department of Entomology, Zoological Museum, Moscow State University, B. Nikitskaya Street, 6, 125009 Moscow K-9, Russia; E-mail: nikitsky_nb@mtu-net.ru

D. S. Schigel, Finnish Museum of Natural History, Botanical Museum, P. O. Box 17, FIN-00014 University of Helsinki, Finland; *Corresponding author's e-mail: schigel@fromru.com

Received 19 February 2003, accepted 19 December 2003

\section{Introduction}

Polypore fungi are a specific group of wood-decomposing Basidiomycetes and an important component of the food chains based on dead wood. One of the main features of polypores is the ability to produce rather large and strong fruiting bodies, which are big and persistent enough to attract and host mycetobiont insects.

Beetles inhabiting polypore fungi are an important part of forest ecosystem, recycling fruiting bodies and being involved in the spore dispersal of the wood-rotting fungi. The beetle fauna of the Moscow (administrative, $~ 54^{\circ} 15^{\prime}-56^{\circ} 52^{\prime}$ $\left.\mathrm{N}, 35^{\circ} 8^{\prime}-40^{\circ} 14^{\prime} \mathrm{E}\right)$ region is now rather well known (Nikistsky et al. 1995, 1996, 1998, 2001, 2002) but the ecology of beetles inhabiting polypores, their host preferences and feeding habits, and beetle complexes in certain polypore species have not been frequently investigated.

Active studies on the biology of mycetophilous beetles started in the 1930's (Donisthorpe 1931, 1935, Benick 1952, Palm 1959, PaviourSmith 1960). General data on mycetophilous beetles for the European part of Russia were collected by Nikitsky (1989, 1993), Kompantsev (1982, 1984) and Kompantseva (1987a-c). Krasutsky (1990, 1996, 1997, 2000) carried out extensive studies of basidiomycete inhabiting beetles in Ural mountains and Western Siberia. Most of the works in Russia focused on the feeding preferences of single beetle species. However, much is still unknown on both the food preferences of certain species, and on the beetle fauna 
of certain polypores. Fungus-beetle interactions are particularly poorly known. In this paper we summarize data on beetle inhabitants of polypore fungi of the Moscow region.

\section{Material and methods}

Field studies were carried out in 1995-1998 in different parts of the Moscow region. The majority of the field material was collected in coniferous and spruce-deciduous mixed forests. The predominant tree species in the region are Picea abies (L.) Karst., Pinus sylvestris L., Betula pendula Roth., Betula pubescens Ehrh., Populus tremula L., Tilia cordata Mill., Alnus glutinosa Gaertn., Salix spp. and Quercus robur L.

Imago and larvae were collected and preserved (larvae in 70\% alcohol) for further identification. Fruiting bodies with beetle larvae were taken in plastic bags and boxes together with substrate for rearing, kept for $2-3$ months in $+4^{\circ} \mathrm{C}$, and then exposed in room temperature for further two months before the checking of the rearing results.

Beetle specimens, preserved in the Zoological Museum of the Moscow State University were studied. Beetle and polypore specimens are preserved in the Zoological Museum of the Moscow State University and partly at the Department of Enotomology, Biological Faculty, Moscow State University. Fungal identification was performed by Dr. T. N. Barsukova and Dr. M. A. Bondartseva. Fungal nomenclature follows Niemelä (2001), names which are not included in this book are given according to Bondartseva \& Parmasto (1986) and Bondartseva (1998). Beetle nomenclature is given according to Silfverberg (1992) and Nikitsky et al. (1996, 1998, 2001).

\section{Results}

Analysis included 261 species of mycetophilous beetles (Appendix) linked to 61 polypore species. Larvae of staphylinid beetles are still not well known and in many cases they are difficult to identify, thus they are not included in our study. The list of polypore species below is given in an alphabetic order because the systematics of the
Basidiomycetes is still unsettled and no good division into families can be made. Beetle lists (cases with both imago and larvae reared were treated separately from those with only imago collected) within each ecological group in every fungal host are given in an alphabetic order within each family without family name specifications. The "imago only" group included also beetles collected on polypore basidiocarps covered by anamorphic fungi, those came during the polypore sporulation period, and possibly, visitors of myxomycete plasmodia, covering polypores. Larvae of these beetles were not studied. A full systematic list of beetles found is given in Appendix.

Our aim was to document beetles separately in all the taxonomically-complicated or difficult groups of polypore species, including as detailed identification of the fungus as possible. Several valid species have been described on the basis of taxa originally published as forms, and it is easy to summarise data on two fungal host species, but no way to re-divide them, if documented collectively.

Unfortunately, in some cases (Daedaleopsis confragosa - Daedaleopsis tricolor; Trametes velutina - T. pubescens; Heterobasidion annosum - H. parviporum; Phellinus igniarius $P$. nigricans $-P$. cinereus) information on some species had to be given collectively because of recent changes in polypore systematics or because the species was given in a wide sense. The number of studied fruiting bodies of each polypore species is given in parentheses after the species name. We studied only inhabited fruiting bodies.

\subsection{Antrodia serialis (Fr.) Donk (70)}

Larvae and imago reared: Epuraea variegata.

\subsection{Bjerkandera adusta (Willd.: Fr.) P. Karst. (221)}

Larvae and imago reared: Dacne bipustulata, $C$. comptus, Ennearthron cornutum, Sulcacis fronticornis, S. affinis, Mycetophagus quadripustulatus, M. ater, M. piceus. (Type specimens of the related species Mycetophagus salicis Brisout de Barneville, 1862, preserved in $\mathrm{Mu}-$ seum d'Historie Naturelle Entomologie, Paris 
were not studied. Only Mycetophagus piceus (Fabricius, 1777) name is used.)

Imago only: Acrulia inflata, Atheta britanniae, A. crassicornis, A. fungi, A. pallidicornis, Dinaraea aequata, Proteinus brachypterus, Scaphidium quadrimaculatum, Scaphisoma agaricinum, S. boleti, S. subalpinum, Thymalus oblongus, Cerylon deplanatum, Orthoperus rogeri, Tetratoma ancora.

\subsection{Cerrena unicolor (Bull.: Fr.) Murrill (83)}

Larvae and imago reared: C. comptus, C. hispidus, C. micans, Sulcacis affinis, S. fronticornis.

Imago only: Scaphidium quadrimaculatum, Scaphisoma agaricinum, Thymalus oblongus, Epuraea variegata, Cerylon ferrugineum, Scaphidema metallicum.

\subsection{Climacocystis borealis (Fr.) \\ Kotl. \& Pouzar (35)}

Larvae and imago reared: Cis comptus, Ennearthron cornutum, E. laricinum, Mycetophagus multipunctatus, Diaperis boleti.

Imago only: Corticaria longicollis, Latridius minutus, Cryptophagus badius, Orthoperus corticalis.

\subsection{Daedalea quercina Fr. (125)}

Imago only: Atheta pallidicornis, Bolitochara obliqua, B. pulchra, Gyrophaena strictula, Phloeocharis subtilissima, Scaphisoma agaricinum, S. balcanicum, S. subalpinum, Thymalus oblongus.

\subsection{Daedaleopsis confragosa (Bolton.: Fr.)}

\section{J. Schröt.}

\subsection{Daedaleopsis tricolor (Bull.: Fr.) Bondartsev \& Singer (220)}

Larvae and imago reared: Cis comptus, Ennearthron cornutum, Sulcacis fronticornis, Thymalus oblongus, Epuraea distincta, Mycetophagus multipunctaus, M. piceus, Litargus connexus.

Imago only: Anisotoma humeralis, Agaricochara latissima, Gyrophaena strictula, Oligota granaria, Cerylon histeroides, Dienerella filum,
Mycetophagus ater, M. quadripustulatus.

Separate collections for these two polypore species are still few. In addition to $D$. tricolor the following larvae and imagos were recorded: Dacne bipustulata, Tritoma subbasalis, Cis boleti, C. comptus, Ennearthron cornutum.

\subsection{Datronia mollis (Sommerf.: Fr.) Donk (50)}

Larvae and imago reared: Ennearthron cornutum.

Imago only: Cyllodes ater.

\subsection{Fistulina hepatica Schaeff.: Fr. (12)}

Larvae and imago reared: Dacne bipustulata, Triphyllus bicolor.

Imago only: Megarthrus hemipterus, Proteinus atomarius, Velleius dilatatus, Epuraea contractula, Cryptophagus abietis. Cryptophagus pubescens was found once.

\subsection{Fomes fomentarius (L.: Fr.) Fr. (823)}

Many beetle species live in the basidiocarps of this polypore. However, only some of them could be found in the fruiting bodies at the larval stage.

Larvae and imago reared: Sepedophilus bipustulatus, S. marshami, S. pedicularius, Dorcatoma dresdensis, D. lomnickii, D. robusta, Cis glabratus (untypical host), C. jacquemartii (the predominant $C$ is species), $C$. lineatocribratus, $C$. alter, Ennearthron cornutum, Ropalodontus strandi (see footnote in Appendix), Bolithophagus reticulatus, Neomida haemorrhoidalis.

Epuraea variegata and E. biguttata were reared from decomposed fruiting bodies.

The larvae of Leiestes seminigra, Melandrya dubia, Tomoxia bucephala, Variimorda villosa and Upis ceramboides develop in the white rot caused by this fungus.

Imago only: Agathidium confusum (N. N. Kotelenets unpubl.), A. laevigatum (rather rare), A. nigripenne, A. rotundatum, Amphicyllis globus, Anisotoma axillaris, A. castanea, A. glabra (N. N. Kotelenets unpubl.), A. humeralis, Acrulia inflata, Atheta boletophila, A. fungi, A. nigricornis, A. pallidicornis, A. paracrassicornis, $A$. picipes, A. pittionii, A. sodalis, Bolitochara 
mulsanti, B. obliqua, B. pulchra, Caryoscapha limbatum, Dinaraea aequata, Euryusa castanoptera, Gyrophaena affinis, G. fasciata, G. manca, G. nana, G. strictula, Haploglossa villosula, Leptusa pulchella, Placusa tachyporoides, Phymatura brevicollis, Scaphidium quadrimaculatum, Scaphisoma agaricinum, S. boreale, S. subalpinum, Sepedophilus littoreus, Peltis grossa, Cyllodes ater, Epuraea concurrens, E. contractula, E. limbata, E. silacea, E. unicolor, Glischrochilus grandis, G. hortensis, Pocadius ferrugineus, Rhizophagus bipustulatus, $R$. dispar, R. parvulus, Aspidiphorus orbiculatus, Atomaria alpina, Cryptophagus setulosus, Triplax russica, Cerylon deplanatum, C. ferrugineum, C. histeroides, Orthoperus corticalis, Corticaria elongata, C. impressa, C. lapponica, C. rubripes, Cortinicara gibbosa, Dienerella filum, Enicmus rugosus, E. fungicola, Latridius brevicollis, L. consimilis, L. hirtus, L. minutus, Bitoma crenata, Litargus connexus, Mycetophagus ater, $M$. decempunctatus, $M$. piceus, $M$. qudripustulatus, Tetratoma ancora, Melandrya dubia, Orchesia micans. Single finds of Cyphea curtula, Cyphon pubescens and Upis ceramboides were made.

\subsection{Fomitopsis pinicola (J. Sowerby: Fr.) P. Karst. (820)}

Larvae and imago reared: Dorcatoma punctulata (in Moscow region living almost exclusively in the fruiting bodies of this common fungus), Cis alter, C. glabratus, C. jacquemartii, Ennearthron cornutum, E. laricinum, Diaperis boleti.

Larvae of Peltis grossa and Ostoma ferruginea are feeding mostly on brown rot caused by the mycelium of this polypore, but sometimes they can inhabit the basidiocarps as well.

Imago only: Anisotoma humeralis, $A$. castanea [these two species were found by N. N. Kotelenets (unpubl.)], Bolitochara mulsanti, $B$. obliqua, Dinaraea aequata, Phymatura brevicollis, Placusa tachyporoides, Scaphisoma agaricinum, S. boleti, S. inopinatum, S. subalpinum, Grynocharis oblonga, Ostoma ferruginea, Peltis grossa, Thymalus oblongus, Cyllodes ater, Epuraea variegata, E. concurrens, Pocadius ferrugineus, Atomaria alpina, Pteryngium crenatum. The most abundant spe- cies on the hymenophore surface is Gyrophaena boleti.

\subsection{Funalia trogii (Berk.) Bondartsev \& Singer (290)}

Larvae and imago reared: Tritoma bipustulata, Cis comptus, Ennearthron cornutum, E. laricinum, Octotemnus glabriculus, Sulcacis affinis, S. bidentulus.

Imago only: Dinaraea aequata, Gyrophaena manca, Scaphisoma balcanicum, S. boreale.

\subsection{Ganoderma lipsiense (Batsch) G. F. Atk. (692) (= Ganoderma applanatum (Pers.) Pat.)}

Larvae and imago reared: Dorcatoma dresdensis (mostly on Alnus), D. lomnickii, Epuraea variegata, Cis jacquemartii, C. alter, Ennearthron cornutum, Mycetophagus decempunctatus, M. piceus.

Neomida haemorrhoidalis can also develop in this fungus, but the main substrate for larvae is Fomes fomentarius. A single rearing of Cis comptus was obtained.

Imago only: Aleochara moerens, Atheta aeneipennis, A. crassicornis, A. diversa, A. euryptera, A. fungi, A. pallidicornis, A. paracrassicornis, A. pilicornis, A. pittionii, A. sodalis, A. subtilis, Bolitochara mulsanti, Dinaraea aequata, D. linearis, Gyrophaena fasciata, Lordithon thoracicus, Scaphisoma agaricinum, S. subalpinum, Atomaria apicalis, Cerylon fagi, C. ferrugineum. Single imago of Scaphisoma boreale collected.

\subsection{Gloeophyllum abietinum (Bull.: Fr.) P. Karst. (93)}

Larvae and imago reared: Curtimorda bisignata (more common in this fungus, than in the other Gloeophyllum species), C. maculosa. Larvae pupate in the brown rotted wood under the fruiting bodies.

\subsection{Gloeophyllum protractum (Fr.) Imazeki (82)}

Larvae and imago reared: Curtimorda bisignata, C. maculosa. 


\subsection{Gloeophyllum sepiarium (Wulfen: Fr.) P. Karst. (102)}

Larvae and imago reared: Curtimorda bisignata, C. maculosa. Larvae pupate in the brown rotted wood under the fruiting bodies.

\subsection{Gloeophyllum trabeum (Pers.: Fr.) Murrill (82)}

Larvae and imago reared: Curtimorda bisignata. Host fungus is yet to be confirmed.

\subsection{Hapalopilus rutilans (Pers.: Fr.) P. Karst. (53)}

Larvae and imago reared: Sulcacis affinis, Hallomenus axillaris, $H$. binotatus (both species develop in the context of fruiting body). Sometimes larvae of Orchesia fasciata, living mostly in decayed wood, were found in the fruiting body.

\subsection{Genus Heterobasidion Bref. (26)}

Two polypore species Heterobasidion annosum (Fr.) Bref. and $H$. parviporum Niemelä \& Korhonen have been separated by Niemelä \& Korhonen (1998).

Larvae and imago reared: The only rearing of Cis lineatocribratus was done without host tree specification and hence the species of Heterobasidion cannot be concluded. Further studies on the beetle fauna of these economically important polypore species are needed.

\subsection{Hyphodontia paradoxa (Schrad.: Fr.) E. Langer \& Vesterhoff (91) (=Schizopora paradoxa (Schrad.: Fr.) Donk)}

Larvae and imago reared: Phryganophilus auritus larvae develop in the white rot caused by the fungus.

Imago only: Acrulia inflata, Cis comptus.

\subsection{Inocutis rheades (Pers.) Fiasson \& Niemelä (192) (= Inonotus rheades (Pers.) Bondartsev \& Singer)}

Larvae and imago reared: Dorcatoma dresdensis, Ennearthron cornutum, Mycetophagus piceus,
Orchesia micans (the predominant species of this fungus in the Moscow region); single rearing of Tritoma subbasalis was conducted.

Imago only: Scaphisoma agaricinum, $S$. subalpinum, Cerylon fagi.

\subsection{Inonotus dryadeus (Pers.: Fr.) Murrill (71)}

Imago only: Atheta oblita.

\subsection{Inonotus hispidus (Bull.: Fr.) P. Karst. (82)}

Larvae and imago reared: Dorcatoma dresdensis, Dacne bipustulata, Ennearthron cornutum, Mycetophagus piceus, Orchesia micans. Larvae of Anaspis marginicollis (and some other Anaspis species) are mostly restricted to dead wood material, but this species can also develop in the polypore basidiocarps.

Imago only: Atheta liturata, Cryptophagus dentatus, Corticaria longicollis.

\subsection{Inonotus obliquus (Pers: Fr.) Pilát (89)}

Larvae and imago reared: Dorcatoma dresdensis, D. substriata, Triplax russica (larvae collected only at this fungus in the Moscow region), Ennearthron cornutum, Epuraea silacea, Mycetophagus ater, Mycetophagus decempunctatus (dominant species in this fungus), $M$. piceus, M. quadripustulatus, Abdera affinis, Orchesia micans. Globicornis emarginata larvae were found on a dead fruiting body of this polypore.

Imago only: Atheta boletophila, A. castanoptera, Carphacis striatus, Megarthrus hemipterus, Scaphisoma agaricinum, Lordithon lunulatus, Pentanota meuseli (single individual), Philonthus succicola. Rotten basidiocarps also attract Nicrophorus vespilloides, Oiceoptoma thoracica, Lordithon exoletus and Geotrupes stercorosus.

\subsection{Inonotus radiatus (J. Sowerby: Fr.) P. Karst. (480)}

Larvae and imago reared: Dorcatoma dresdensis, D. substriata, Dacne bipustulata, C. glabratus, 
C. jacquemartii, Ennearthron cornutum, Sulcacis fronticornis, Mycetophagus decempunctatus, M. multipunctatus, M. piceus, Abdera affinis, A. flexuosa (both species of Abdera develop in the fungus, but the last-mentioned is more common), Orchesia fusiformis, O. micans. Globicornis emagrinata larvae were collected on dried fruiting bodies.

Imago only: Dinaraea aequata, Cryptophagus dentatus.

\subsection{Laetiporus sulphureus (Bull.: Fr.) Murrill (460)}

Larvae and imago reared: Dacne bipustulata, Ennearthron cornutum, Mycetophagus ater, $M$. decempunctatus, M. multipunctatus, M. piceus, Mycetophagus quadripustulatus (dominant species within this beetle genus), Hallomenus axillaris, $H$. binotatus, Diaperis boleti, Eledona agaricola, Pentaphyllus testaceus.

Larvae of Dorcatoma flavicornis, D. chrysomelina and Ennearthron palmi (single find) develop in the brown rot caused by this fungus and can be found in between basidiocarp and wood.

Imago only: Aleochara sanguinea, Anotylus nitidulus, Atheta britanniae, A. castanoptera, A. crassicornis, A. celata, A. fungi, A. gagatina, $A$. liturata, A. oblita, A. pilicornis, A. paracrassicornis, A. pittionii, A. ravilla, A. subtilis, Autalia longicornis, Gyrophaena affinis, G. fasciata, G. manca, G. orientalis, G. pulchella, Lordithon lunulatus, Scaphidium quadrimaculatum, Oxypoda alternans, Phloeonomus pusillus, Proteinus atomarius, Quedius cruentus, Q. brevicornis, Cryptopleurum minutum, Ghathoncus buyssoni (predator), Pocadius ferrugineus, Atomaria apicalis, Cryptophagus dentatus, C. scanicus, C. setulosus, Triplax russica, Orthoperus atomus, O. corticalis.

Imago on decomposed basidiocarps: Nicrophorus vespilloides, Oiceoptoma thoracica, Catops nigricans, C. nigrita, Sciodrepoides watsoni, Atheta dadopora, A. harwoodi, A. laticollis, A. nigricornis, A. nigritula, A. sodalis, Bolitochara lucida, B. pulchra, Megarthrus depressus, M. hemipterus, M. nitidulus, Omalium rivulare, Philonthus succicola, P. carbonarius (more common than the previous species),
Proteinus macropterus, Cercyon impressus, $C$. lateralis, Megasternum obscurum, Geotrupes stercorosus, Cis bidentatus, Ennearthron laricinum, Sulcacis fronticornis, Mycetophagus quadriguttatus.

Corticaria alleni was collected on the brown rot caused by the fungus.

\subsection{Lenzites betulinus (L.: Fr.) Fr. (171)}

Larvae and imago reared: Tritoma subbasalis, Cis boleti, C. comptus, C. fissicornis, C. hispidus, C. micans, C. rugulosus, Octotemnus glabriculus, Sulcacis affinis, Wagaicis wagai, Orchesia fusiformis.

Imago only: Agathidium seminulum, Atheta britanniae, Cerylon deplanatum, C. histeroides, Corticaria serrata. Latridius consimilis individuals were found on decomposed fruiting bodies, $L$. hirtus was found only once.

\subsection{Phellinus alni (Bondartsev) Parmasto} (12)

Larvae and imago reared: Cis jacquemartii, Ennearthron cornutum, Sulcacis fronticornis.

\subsection{Phellinus igniarius (L.: Fr.) Quél. (310) (including $P$. cinereus (Niemelä) M. Fischer and $P$. nigricans (Fr.) P. Karst.)}

Larvae and imago reared: Dorcatoma lomnickii, D. dresdensis and Ennearthron cornutum are main larval inhabitats in basidiocarps together with Cis jacquemartii, Abdera affinis and less frequently Bolitophagus reticulatus. Cis lineatocribratus was reared only once.

Predator larvae of Korynetes caeruleus and Tillus elongatus come to the polypore to hunt for the larvae of Dorcatoma. Denticollis linearis larvae are also predators; typical host for them is rotten wood, from where they can come to the fruiting body and can pupate inside the fungus.

In the white rot caused by the fungus the larvae of Melandrya dubia and Tomoxia bucephala develop.

Imago only: Bolitochara obliqua, Gyrophaena affinis, G. bihamata, G. fasciata, $G$. joyioides, G. manca, G. nana, G. strictula, Lordithon thoracicus, Scaphisoma agaricinum, 
Thymalus oblongus, Atomaria alpina, Cryptophagus pseudodentatus, Orchesia micans.

\subsection{Phellinus punctatus (Fr.) Pilát (31)}

Imago only: Tetratoma ancora.

\subsection{Phellinus robustus (P. Karst.) Bourdot \& Galzin (78)}

Larvae and imago reared: Cis glabratus, Ennearthron cornutum.

\subsection{Phellinus tremulae (Bondartsev) Bondartsev \& Borissov (198)}

Larvae and imago reared: Dorcatoma dresdensis, Cis jacquemartii, Ennearthron cornutum, Anaspis arctica.

Imago only: Scaphisoma balcanicum.

\subsection{Piptoporus betulinus (Bull.: Fr.) \\ P. Karst. (398)}

Larvae and imago reared: Epuraea variegata, Dacne bipustulata, Cis glabratus, $C$. jacquemartii, C. lineatocribratus, Ennearthron cornutum, E. laricinum, Sulcacis affinis, Diaperis boleti.

In the white rot of the fungus Leiestes seminigra and Upis ceramboides larvae develop.

Imago only: Agathidium nigripenne (N. N. Kotelenets unpubl.), Anisotoma humeralis, Agaricochara latissima, Atheta britanniae, A. castanoptera, A. crassicornis, A. fungicola, A. gagatina, A. harwoodi, A. nigricornis, A. nigritula, A. pallidicornis, A. picipes, A. sodalis, Bolitochara mulsanti, B. obliqua, Dinaraea aequata, D. angustula, Gyrophaena affinis, Homalota plana (single individual), Lordithon exoletus, L. lunulatus, Oxypoda alternans, Philonthus fimetarius, $P$. carbonarius, $P$. succicola, Phloeocharis subtilissima (single find), Proteinus atomarius, P. brachypterus, Scaphisoma agaricinum, $S$. boleti, Thymalus oblongus, Cyllodes ater, Epuraea silacea, Caenoscelis ferruginea, Litargus connexus, Mycetophagus ater, M. piceus, M. decempunctatus, M. multipunctatus, M. quadripustulatus, Triphyllus bicolor, Tetratoma ancora.
Imago on decomposed basidiocarps: Cercyon lateralis, Megasternum obscurum, Atomaria fuscata, Cryptophagus dentatus, C. pallidus, Latridius consimilis.

\subsection{Polyporus alveolarius (DC.: Fr.) Bondartsev \& Singer (39)}

Imago only: Tritoma subbasalis.

\subsection{Polyporus brumalis (Pers.: Fr.) Fr. (14)}

Larvae and imago reared: Tritoma bipustulata.

\subsection{Polyporus coronatus Rostk. (10)}

Imago only: Dinaraea aequata, D. angustula, Gyrophaena affinis, Lordithon lunulatus.

\subsection{Polyporus melanopus (Pers.: Fr.) Fr.} (29)

Imago only: Sulcacis bidentulus.

\subsection{Polyporus squamosus (Huds.: Fr.) Fr. (362)}

Larvae and imago reared: Epuraea silacea, Dacne bipustulata, Litargus connexus, Mycetophagus ater, M. decempunctatus, M. piceus, M. multipunctatus, M. quadripustulatus, Diaperis boleti.

Imago only: Agathidium seminulum, Anopleta corvina, Anotylus nitidulus, Atheta britanniae, A. castanoptera, A. celata, A. crassicornis, A. euryptera (single individual), A. fungi, A. fungicola, A gagatina, A. laticollis, A. liturata, A. nigra, A. nigricornis, A. oblita, A. pallidicornis, A paracrassicornis, A. picipes, $A$. pittionii, A. sodalis, A. subtilis, Bolitochara lucida, B. obliqua, Dinaraea aequata, Gyrophaena affinis, G. bihamata, G. fasciata, G. gentilis, G. joyi, G. joyioides, G. lucidula, G. manca, G. minima, G. nana, G. obsoleta, G. poweri, $G$. strictula, G. transversalis, Lordithon lunulatus, $L$. thoracicus, Megarthrus denticollis, M. depressus, M. sinuatocollis, Oxyporus rufus, Philonthus carbonarius, $P$. fimetarius, $P$. succicola, Phloeonomus pusillus, Proteinus atomarius, Quedius cruentus, Scaphisoma subalpinum, 
Sepedophilus littoreus, S. testaceus, Nossidium pilosellum, Pocadius ferrugineus, Atomaria apicalis, Cryptophagus scanicus, C. setulosus, Pteryngium crenatum, Triplax russica, Cerylon fagi, Sericoderus lateralis, Hallomenus axillaris. Omalium rivulare is abundant on fruiting bodies in autumn.

Imago on decomposed basidiocarps: Sciodrepoides fumatus, Philonthus subuliformis, Proteinus brachypterus, P. ovalis, Cercyon impressus, C. lateralis (dominant species in the fungus), Cryptopleurum minutum, Megasternum obscurum, Epuraea limbata, Glischrochilus hortensis, Atomaria pusilla, Cryptophagus acutangulus, C. dentatus, C. saginatus, Orthoperus corticalis.

\subsection{Postia caesia (Schrad.: Fr.) P. Karst.}

Larvae and imago reared: Hallomenus binotatus.

\subsection{Postia fragilis (Fr.) Jülich (9)}

Larvae and imago reared: Hallomenus axillaris, $H$. binotatus (last species is more common).

\subsection{Pycnoporellus fulgens (Fr.) Donk (52)}

Larvae and imago reared: Ennearthron cornutum, Hallomenus axillaris, H. binotatus. Larvae of Atomaria affinis develop both in basidiocarps and the brown rot of the fungus.

Imago only: Grynocharis oblonga, Ostoma ferruginea.

\subsection{Pycnoporus cinnabarinus (Jacq.: Fr.) P. Karst. (49)}

Larvae and imago reared: Sulcacis affinis. Imago only: Hallomenus binotatus.

\subsection{Rigidoporus corticola (Fr.) Pouzar (29)}

Imago only: Acrulia inflata, Atheta pallidicornis, Lordithon lunulatus, Scaphidium quadrimaculatum, Scaphisoma agaricinum, S. boreale.

\subsection{Rigidoporus latemarginatus (Durieu \& Mont.) Pouzar (17)}

Imago only: Scaphisoma assimile, S. boreale.

\subsection{Rigidoporus ulmarius (J. Sowerby: Fr.) Imazeki (30)}

Imago only: Gyrophaena fasciata, G. manca, Sepedophilus testaceus.

\subsection{Spongipellis spumea (J. Sowerby: Fr.) Pat. (23)}

Larvae and imago reared: Cis micans.

\subsection{Trametes cervina (Schwein.) Bres. (16)}

Larvae and imago reared: Dacne bipustulata, Cis boleti, C. hispidus, Sulcacis bidentulus.

\subsection{Trametes gibbosa (Pers.) Fr. (92)}

Fungi of the genus Trametes are mostly eaten by larvae of Cis comptus, Cis rugulosus, Sulcacis affinis, S. fronticornis, Octotemnus glabriculus and some other Ciidae. Trametes gibbosa was for some time considered to belong to the monotypic genus Pseudotrametes (P. gibbosa (Pers.) Bondartsev \& Singer). Present knowledge of the beetle communities in polypores supports this separation.

Larvae and imago reared: only Sulcacis fronticornis was reared from basidiocarps collected in the research area.

Imago only: Atheta pilicornis, Phloeonomus pusillus.

\subsection{Trametes hirsuta (Wulfen: Fr.) Pilát (198)}

Larvae and imago reared: Tritoma bipustulata, $T$. subbasalis, Cis boleti, C. comptus, C. fissicornis, C. hispidus, C. micans, Sulcacis affinis, S. fronticornis, Wagaicis wagai, Orchesia fusiformis.

Imago only: Atheta britanniae, A. crassicornis, A. gagatina, Dacne bipustulata. 


\subsection{Trametes ochracea (Pers.)}

Gilb. \& Ryvarden (154)

Larvae and imago reared: Tritoma subbasalis, Cis boleti, C. comptus, C. fissicornis, C. hispidus, C. micans, Octotemnus glabriculus, Sulcacis affinis, S. fronticornis, Wagaicis wagai, Orchesia fusiformis.

Imago only: Dinaraea aequata, Bitoma crenata.

\subsection{Trametes pubescens (Schumach.: Fr.) Pilát (182) (including T. velutina (Fr.) G. Cunn.)}

Larvae and imago reared: Tritoma bipustulata, $T$. subbasalis, Cis boleti, C. comptus, C. fissicornis, C. hispidus, Octotemnus glabriculus, Sulcacis affinis, S. fronticornis, Wagaicis wagai, Orchesia fusiformis.

Imago only: Atheta crassicornis, Gyrophaena affinis, Latridius hirtus, Ennearthron laricinum, Abdera affinis, A. flexuosa.

\subsection{Trametes suaveolens (L.: Fr.) Fr. (56)}

Larvae and imago reared: Cis boleti, C. fissicornis, C. hispidus, C. micans.

\subsection{Trametes versicolor (L.: Fr.) Pilát (202)}

Larvae and imago reared: Tritoma subbasalis, Cis boleti, C. comptus, C. fissicornis, C. hispidus, C. micans, Octotemnus glabriculus, Sulcacis affinis, S. fronticornis, Wagaicis wagai, Orchesia fusiformis. Also Cis glabratus was reared from the basidiocarps of this species, but it is a rather rare, untipycal substrate for this beetle.

Imago only: Agaricochara latissima, Atheta fungi, Dinaraea aequata, Scaphisoma agaricinum, Dacne bipustulata.

\subsection{Trichaptum abietinum (Dicks.: Fr.) Ryvarden 3.55 Trichaptum fuscoviolaceum (Ehrenb.: Fr.) Ryvarden (380)}

We could not find differences in the beetle fauna of these two Trichaptum species.

Larvae and imago reared: Cis punctulatus,
Wanachia triguttata, Zilora elongata.

\subsection{Trichaptum pargamenum (Fr. in Klotzsch) G. Cunn. (181) (= Trichaptum biforme (Fr. in Klotzch) Ryvarden)}

Larvae and imago reared: Cis comptus, $C$. jacquemartii, Ennearthron cornutum, Ropalodontus strandi. Occasional rearings of Cis punctulatus were also conducted.

Imago only: Epuraea variegata, Scaphisoma agaricinum.

\subsection{Tyromyces chioneus (Fr.) P. Karst. (73)}

Larvae and imago reared: This fungus is the main food source for Hallomenus axillaris and $H$. binotatus larvae in the Moscow region.

Imago only: Cryptophagus abietis.

\section{Discussion}

There are three main relationship groups between beetles and polypores in Moscow region.

The first group consists of larvae of the truly mycetophagous species that develop inside or on the surface of polypore basidiocarps and feed on fungus mycelia or spores. This group includes species of Staphylinidae, Dorcatominae, Trogossitidae (Thymalus), Nitidulidae (Epuraea contractula, E. distincta, E. variegata and E. silacea), Erotylidae (Tritoma spp., Dacne bipustulata and Triplax russica), almost all Ciidae and Mycetophagidae species, and part of the species of Tetratomidae (Hallomenus), Melandryidae (Orchesia micans, O. fusiformis, all species of Abdera (subgenus Caridua), Wanachia and Zilora genera), Mordellidae (Curtimorda) and Tenebrionidae (Bolitophagus, Eledona, Diaperis, Neomida and Pentaphyllus).

Certain polyphagous larvae of Ciidae utilize the highest number of fungus substrates (Ennearthron cornutum develops in 20 species of polypores, Cis comptus uses 16 species), Erotylidae (Dacne bipustulata colonizes 10 polypore species) and Anobiidae (Dorcatoma dresdensis develops in eight polypore species).

Some species of the truly mycetophagous beetles are monophagous, developing only in a 
certain polypore species. Dorcatoma punctulata (inhabiting Fomitopsis pinicola), Epuraea distincta (Daedaleopsis confragosa), Triplax russica (Inonotus obliquus), Bolitophagus reticulatus (Fomes fomentarius), Eledona agaricola and Pentaphyllus testaceus (Laetiporus sulphureus) are monophagous.

The larvae of oligophagous beetles feed inside the fruiting bodies of the polypores of a single genus: Cis puctulatus, Wanachia triguttata, Zilora elongata (Trichaptum spp. on conifers) and Curtomorda (Gloeophyllum spp.).

The most speciose group includes all the beetle species collected at the imaginal stage only. Some species can be found only on fruiting bodies covered by anamorphic fungi, or on polypores partly covered by myxomycete plasmodium. These beetle species probably use polypores as sources for food at their imaginal stages.

Mycetoxenous beetles occasionally visit basidiocarps of polypore fungi but do not usually eat fungal parts. Some of them are predators, like Philonthus spp., Quedius spp., clerid larvae of the genera Tillus, and Korynetes that feeds on Anobiidae larvae. Also, larvae of Cercyon spp., Megasternum obscurum, Cryptopleurum spp., Gnathoncus buyssoni sometimes feed on larvae and pupae of other insects. Examples of dungand carrion-eating beetles found on polypore fruiting bodies are Geotrupes stercorosus, Oiceoptoma thoracica and Nicrophorus vespilloides.

One of the very specialized families of beetles that develop in polypores is Ciidae. The host preferences of these species are mostly determined by the hardness of the fruiting body, not by the close systematical relations of polypore genera. Fomes, Fomitopsis, Ganoderma and Phellinus polypores are colonized mostly by $C i$ s species of the "jacquemartii" group (C. lineatocribratus, C. alter, $C$. glabratus, $C$. jacquemartii). The group "micans" (C. hispidus, C. micans, C. boleti), on the other hand, utilizes annual and softer polypores like Trametes, Lenzites and Daedaleopsis. Cis punctulatus develops in Trichaptum species on conifers. The only Cis species with a really wide trophic spectrum is Cis comptus.

Apart from Cis comptus, only Ennearthron cornutum (that prefers hard basidiocarps) and Dacne bipustulata (Erotylidae) have rather wide host-fungus range. The majority of the other mycetophagous beetles shows some preferences for a systematical or structure-based group of substrates.

Sometimes the influence of host tree can be detected, like in the case of Trichaptum. Two species of Trichaptum grow on coniferous trees and have a uniform beetle fauna, but Trichaptum pargamenum (that grows on deciduous trees) is colonized by a different set of beetles that live also in Trametes and Lenzites betulinus polypores of deciduous trees.

According to our observations, the most diverse communities of polypore-inhabiting beetles can be found along forest margins with a mixture of different-aged coniferous and deciduous trees.

Several beetle species are spring active, while others, like such that often hibernate as larvae (e.g. Dorcatoma, Hallomenus, Orchesia, Abdera subgenus Caridua, Wanachia and Curtimorda) and emerge later, are usually active in midsummer. Most of the species are monovoltinous, and some beetles that develop in hard, perennial fruiting bodies (Dorcatoma and Bolitophagus) may develop for more than one year.

A total of 261 beetle species connected with polypore fungi were found in the Moscow region. Of these, 174 species were found in polypores only as imagos, while 87 species develop in polypores at their larval stages. The actual species diversity of polypore inhabitants is probably higher. The highest species diversity was found in polypores of deciduous trees: Fomes fomentarius (102 species), Polyporus squamosus (94 species), Laetiporus sulphureus (81 species) and Piptoporus betulinus (62 species). In the Moscow region, mono- and oligophagous beetles developing in polypores were found in the genera Dorcatoma, Epuraea, Triplax, Cis, Curtimorda, Abdera (subgenus Caridua), Wanachia, Eledona and Pentaphyllus. Ennearthron cornutum (20 species of polypores) and Cis comptus (16 species) have the highest number of host fungi.

Acknowledegements. We would like to express our thanks to Dr. M. A. Bondartseva (St. Petersburg) and Dr. T. N. Barsukova for kind help with polypore identification, to Dr. A. V. Kompantsev and Dr. T. V. Kompantseva for identification of some beetle specimens and to Dr. R. D. Zhantiev and Dr. E. A. Dunayev (Moscow) for valuable comments. Dr. H. Meljon (Uppsala), Dr. M. Sörennsen 
(Lund), Dr. L. Zerche (Eberswalde) kindly provided type specimens. A research grant from the Ministry of Environment, Finland (YM131/5512/2002) is gratefully acknowledged. Dr. T. Niemelä (Helsinki) kindly revised the manuscript.

\section{References}

Benick, L. 1952: Pilzkäfer und Käferpilze. Ökologishe und statistische Untersuchungen. - Acta Zool. Fenn. 70: 1-309.

Bondartseva, M. A. 1998: (Definitorum fungorum Rossiae. Ordo Aphyllophorales. Fasc. 2.) - Nauka, St. Petersburg. 391 pp. [In Russian]

Bondartseva, M. A. \& Parmasto, E. H. 1986 (Clavis diagnostica fungorum USSR. Ordo Aphyllophorales. Fasc. 1.) — Nauka, Leningrad. 192 pp. [In Russian]

Donisthorpe, H. 1931: Coleoptera found in the "birch bracket" fungus Polyporus betulinus. — Ent. Rec. 43: 14.

Donisthorpe, H. 1935: The british fungicolous Coleoptera. — Entomol. Mon. Mag. 71: 21 - 31 .

Kompantsev, A. V. 1982: (Morpho-ecological pecularities of Erotylidae (Coleoptera) larvae - inhabitants of the higher fungi fruit bodies). - In: Morpho-ecological adaptations of insects in terrestrial communities: 8191. Nauka, Moscow. [In Russian]

Kompantsev, A. V. 1984: (Beetle complexes linked to the main wood-rotting fungi in the forests of Kostroma region.) - In: Animal world of southern taiga: 191-196. Nauka, Moscow. [In Russian]

Kompantseva, T. V. 1987a: (Larvae of the mycetophilous tenebrionid beetles of the tribe Diaperini (Coleoptera, Tenebrionidae).) - In: Ecology and morphology of insects - inhabitants of fungal substrates: 65-87. Nauka, Moscow. [In Russian]

Kompantseva, T. V. 1987b: (Ecological pecularities of xylophilous and mycetophilous darkling beetles [Coleoptera, Tenebrionidae].) — In: Ecology and morphology of insects - inhabitants of fungal substrates: 45-56. Nauka, Moscow. [In Russian]

Kompantseva, T. V. 1987c: (Larvae of the tenebrionid beetles of the tribe Bolitophagini (Coleoptera, Tenebrionidae).) — Entomol. Rev. 66: 602-613. [In Russian]

Krasutsky, B. V. 1990: (Beetle communities linked to the main wood-rotting fungi of Pripyshmin pine woods in Western Siberia.) - In: Ecological-floristic studies on spore plants of Ural: 57-67. Russian Acad. Sci., Ural Div., Sverdlovsk. [In Russian]

Krasutsky, B. V. 1996: (Mycetophilous Coleoptera of Ural and Trans-Ural region.) - Ekaterinburg Press, Ekaterinburg. 148 pp. [In Russian]

Krasutsky, B. V. 1997: (Beetles (Coleoptera) mycetobionts of the main wood-destroying fungi of the southern subszone of West Siberian taiga.) - Entomol. Rev. 76: 302-308. [In Russian]

Krasutsky, B. V. 2000: (Mycetophilous beetles (Insecta, Coleoptera) of Ilmen Strict Nature Reserve. System "fungi-insects".): 80-109. — In: Ecology of the processes of biological wood destruction. Ekaterinburg Press, Ekaterinburg. [In Russian]

Niemelä, T. 2001: (Polypores of Finland and adjacent Russia.) - Norrlinia 8: 1-120. [In Russian]

Niemelä, T. \& Korhonen, K. 1998: Taxonomy of the genus Heterobasidion: 27-33. — In: Woodward, S., Stenlid, J., Karjalainen, R. \& Hüttermann, A. (eds.), Heterobasidion annosum, biology, ecology, impact and control. CAB International, Oxon. 589 pp.

Nikitsky, N. B. 1989: (Beetles of the families Tetratomidae and Melandryidae of the Far East of USSR.) - Arch. Zool. Mus. Moscow State Univ., Moscow 27: 3-87. [In Russian]

Nikitsky, N. B. 1993: (Mycetophagid beetles (Coleoptera, Mycetophagidae) of Russia and adjacent countries.) - Moscow State Univ., Moscow. 184 pp. [In Russian]

Nikitsky, N. B. \& Kompantsev, A. V. 1995. (New erotylid species (Coleoptera, Erotylidae) from Far East of Russia with notes on distribution and species biology) Zool. Journal 74: 83-92. [In Russian]

Nikitsky, N. B., Osipov, I. N., Chemeris, M. V., Semenov, V. B. \& Gusakov, A. A. 1996: (Beetles xylobionts, mycetobionts and scarabaeids of Prioksko-Terrasny Biosphere Reserve.) - Arch. Zool. Mus. Moscow State University, Moscow. 36. 197 pp. [In Russian]

Nikitsky, N. B., Semenov, V. B. \& Dolgin, M. M.1998. (Beetles xylobionts, mycetobionts and scarabaeids of Prioksko-Terrasny Biosphere Reserve. Supplementum 1.) - Arch. Zool. Mus. Moscow State University, Moscow. 36. 55 pp. [In Russian]

Nikitsky, N. B. \& Semenov, V. B. 2001. (To the knowledge of the beetles (Coleoptera) of the Moscow region.) Byulleten' Moskovskogo Obshestva Ispytatelei Prirody, Otdel Biologicheskii 106: 38-49. [In Russian]

Nikitsky, N. B. \& Tatarinova, A. F. 2002. (Fauna and ecology of the minute brown scavenger beetles (Coleoptera, Latridiidae) of the European North-East of Russia, with the remarks of xylophilous (and some other) beetles from Moscow region.) - Byulleten' Moskovskogo Obshestva Ispytatelei Prirody, Otdel Biologicheskii 107: 22-25. [In Russian]

Palm, T. 1959: Die Holz und Rinden — Käfer der Süd- und Mittelschwedischen Laubbäume - Opusc. Entomologica Supplementum 16. 374 pp.

Pavior-Smith, K. 1960: The fruiting bodies of macrofungi as habitats for beetles of the family Ciidae (Coleoptera). - Oikos 11: 1-17.

Silfverberg, H. 1992: Enumeratio Coleopterorum Fennoscandiae, Daniae et Baltiae. - Helsingin Hyönteisvaihtoyhdistys, Helsinki. 94 pp. 
Appendix. Systematic list of beetle species (linked to polypores either on imaginal only or both imaginal and larval stages). "Found" column: + = Larvae develop in polypore basidiocarp, using it as a source of food; +/- = Larvae were not found (or they do not use the polypore basidiocarp as food); $-=$ only imagos were found. "Polypore nr." is an index, referring to the text, by polypore species number. It does not indicate directly the fungal host of a given beetle species.

Nr. Family and species

Leiodidae Fleming, 1821

1 Anisotoma humeralis (Fabricius, 1792)

2 Anisotoma axillaris Gyllenhal, 1810

3 Anisotoma castanea (Herbst, 1792)

4 Anisotoma glabra (Kugelann, 1794)

5 Amphicyllis globus (Fabricius, 1792)

6 Agathidium rotundatum (Gyllenhal, 1827)

7 Agathidium confusum Brisout de Barneville, 1863

8 Agathidium seminulum (Linnaeus, 1758)

9 Agathidium nigripenne (Fabricius, 1792)

10 Agathidium laevigatum Erichson, 1845

Silphidae Latreille, 1807

11 Nicrophorus vespilloides Herbst, 1784

12 Oiceoptoma thoracica (Linnaeus, 1758)

Cholevidae Kirby, 1837

13 Sciodrepoides watsoni (Spence, 1815)

14 Sciodrepoides fumatus (Spence, 1815)

15 Catops nigrita Erichson, 1837

16 Catops nigricans (Spence, 1815)

Staphylinidae Latreille, 1802

17 Philonthus fimetarius (Gravenhorst, 1802)

18 Philonthus succicola Thomson, 1860

19 Philonthus subuliformis (Gravenhorst, 1802)

20 Philonthus carbonarius (Gravenhorst, 1802)

21 Velleius dilatatus (Fabricius, 1787)

22 Quedius cruentus (Olivier, 1795)

23 Quedius brevicornis Thomson, 1860

24 Oxyporus rufus (Linnaeus, 1758)

25 Megarthrus depressus (Paykull, 1789)

26 Megarthrus sinuatocollis (Lacordaire, 1835)

27 Megarthrus hemipterus (Illiger, 1794)

28 Megarthrus denticollis (Beck, 1817)

29 Megarthrus nitidulus Kraatz, 1858

30 Proteinus brachypterus (Fabricius, 1792)

31 Proteinus atomarius Erichson, 1840

32 Proteinus ovalis Stephens, 1834

33 Proteinus macropterus (Gravenhorst, 1806)

34 Omalium rivulare (Paykull,1789)

35 Acrulia inflata (Gyllenhal, 1813)

36 Phloeonomus pusillus (Gravenhorst, 1806)

37 Caryoscapha limbatum (Erichson, 1845)

38 Scaphidium quadrimaculatum Olivier, 1790

39 Scaphisoma agaricinum (Linnaeus, 1758)

40 Scaphisoma inopinatum Löbl, 1967

41 Scaphisoma boleti (Panzer, 1793)

42 Scaphisoma subalpinum Reitter, 1881

43 Scaphisoma balcanicum Tamanini, 1954

44 Scaphisoma boreale Lundblad, 1952

45 Scaphisoma assimile Erichson, 1845

46 Anotylus nitidulus (Gravenhorst, 1802)

Found Polypore nr.

\section{$-$}

\section{-}

- $\quad 3.10 ; 3.11$

- 3.10

- $\quad 3.10$

$-\quad 3.10$

3.10

- $\quad 3.27 ; 3.38$

- $\quad 3.10 ; 3.33$

- $\quad 3.10$

- $\quad 3.24$

- $\quad 3.24 ; 3.26$

$-\quad 3.26$

$-\quad 3.38$

- $\quad 3.26$

$-\quad 3.26$

- $\quad 3.33 ; 3.38$

- $\quad 3.24 ; 3.26 ; 3.33 ; 3.38$

- $\quad 3.38$

- $\quad 3.26 ; 3.33 ; 3.38$

- $\quad 3.9$

- $\quad 3.26 ; 3.38$

$-\quad 3.26$

- $\quad 3.38$

- $\quad 3.26 ; 3.38$

- $\quad 3.38$

- $\quad 3.9 ; 3.24 ; 3.26$

- $\quad 3.38$

- $\quad 3.26 ; 3.38$

- $\quad 3.2 ; 3.33 ; 3.38$

- $\quad 3.9 ; 3.26 ; 3.33 ; 3.38$

- 3.38

$-\quad 3.26$

- $\quad 3.26 ; 3.38$

- $\quad 3.2 ; 3.10 ; 3.20 ; 3.43$

- $\quad 3.26 ; 3.38 ; 3.48$

- $\quad 3.10$

- $\quad 3.2 ; 3.3 ; 3.10 ; 3.26 ; 3.43$

- $\quad 3.2 ; 3.3 ; 3.5 ; 3.10 ; 3.11 ; 3.13 ; 3.21 ; 3.24$;

$3.29 ; 3.33 ; 3.43 ; 3.53 ; 3.56$

$-\quad 3.11$

- $\quad 3.2 ; 3.11 ; 3.33$

- $\quad 3.2 ; 3.5 ; 3.10 ; 3.11 ; 3.13 ; 3.21 ; 3.38$

- $\quad 3.5 ; 3.12 ; 3.32$

- $\quad 3.10 ; 3.12 ; 3.13 ; 3.43,3.44$

- $\quad 3.44$

- $\quad 3.26 ; 3.38$ 
Phloeocharis subtilissima Mannerheim, 1830

Carphacis striatus (Olivier, 1794)

Lordithon thoracicus (Fabricius, 1777)

Lordithon exoletus (Erichson, 1839)

Lordithon lunulatus (Linnaeus, 1761)

Sepedophilus littoreus (Linnaeus, 1758)

Sepedophilus testaceus (Fabricius, 1792)

Sepedophilus marshami (Stephens, 1832)

Sepedophilus bipustulatus (Gravenhorst, 1802)

Sepedophilus pedicularius (Gravenhorst, 1802)

Aleochara moerens Gyllenhal, 1827

Aleochara sanguinea (Linnaeus, 1758)

Oxypoda alternans (Gravenhorst, 1802)

Haploglossa villosula (Stephens, 1832)

Pentanota meuseli Bernhauer, 1905

Atheta (Microdota) subtilis (Scriba, 1866)

Atheta (Microdota) pittionii Scheerpeltz, 1950

Atheta (Datomicra) celata (Erichson, 1837)

Atheta (Datomicra) nigra (Kraatz, 1856)

Atheta (Datomicra) dadopora Thomson, 1867

Atheta (Mocyta) fungi (Gravenhorst, 1806)

Atheta (Mycetota) laticollis (Stephens, 1832)

Atheta (Plataraea) nigritula (Gravenhorst, 1802)

Atheta (s. str.) liturata (Stephens, 1832)

Atheta (s. str.) oblita (Erichson, 1839)

Atheta (s. str.) boletophila (Thomson, 1856)

Atheta (s. str.) diversa (Sharp, 1869)

Atheta (s. str.) pilicornis (Thomson, 1852)

Atheta (s. str.) fungicola (Thomson, 1852)

Atheta (s. str.) britanniae Bernhauer et

Scheerpeltz, 1926

Atheta (s. str.) castanoptera (Mannerheim, 1831)

Atheta (s. str.) euryptera (Stephens, 1832)

Atheta (s. str.) crassicornis (Fabricius, 1792)

Atheta (s. str.) paracrassicornis Brundin, 1954

Atheta (s. str.) nigricornis (Thomson, 1852)

Atheta (s. str.) harwoodi Williams, 1930

Atheta (s. str.) ravilla (Erichson, 1839)

Atheta (Alaobia) sodalis (Erichson, 1837)

Atheta (Alaobia) gagatina (Baudi, 1848)

Atheta (Alaobia) pallidicornis (Thomson, 1856)

Atheta (Dimetrota) aeneipennis (Thomson, 1856) -

Atheta (Traumoecia) picipes (Thomson, 1856)

Anopleta corvina (Thomson, 1856)

Dinaraea aequata (Erichson, 1837)

Dinaraea linearis (Gravenhorst, 1802)

Dinaraea angustula (Gyllenhal, 1810)

Gyrophaena pulchella Heer, 1839

Gyrophaena affinis Mannerheim, 1830

Gyrophaena nana (Paykull, 1800)

Gyrophaena gentilis Erichson, 1839

Gyrophaena poweri Crotch, 1866

Gyrophaena minima Erichson, 1837

Gyrophaena fasciata (Marsham, 1802)

Gyrophaena orientalis Strand, 1938

Gyrophaena bihamata Thomson, 1867

Gyrophaena joyi Wendeler, 1924

Gyrophaena joyioides Wusthoff, 1937

Gyrophaena manca Erichson, 1839



$3.24 ; 3.26 ; 3.33 ; 3.38$

$3.13 ; 3.38$

$3.2 ; 3.13 ; 3.26 ; 3.33 ; 3.38 ; 3.49 ; 3.51$

$3.10 ; 3.13 ; 3.26 ; 3.38$

$3.10 ; 3.26 ; 3.33 ; 3.38$

$3.26 ; 3.33$

3.26

$3.10 ; 3.13 ; 3.26 ; 3.33 ; 3.38$

$3.26 ; 3.33 ; 3.38 ; 3.49$

$3.2 ; 3.5 ; 3.10 ; 3.13 ; 3.33 ; 3.38 ; 3.42$

3.13

$3.10 ; 3.33 ; 3.38$

3.38

$3.2 ; 3.10 ; 3.11 ; 3.12 ; 3.13 ; 3.25 ; 3.33 ; 3.36$;

$3.38 ; 3.50 ; 3.53$

$-\quad 3.13$

- $\quad 3.33,3.36$

- $\quad 3.26$

- $\quad 3.10 ; 3.26 ; 3.29 ; 3.33 ; 3.36 ; 3.38 ; 3.51$

- $\quad 3.10 ; 3.29 ; 3.38$

- 3.38

$-\quad 3.38$

- $\quad 3.38$

- $\quad 3.10 ; 3.13 ; 3.26 ; 3.29 ; 3.38 ; 3.45$

- 3.26;

- $\quad 3.29 ; 3.38$

- $\quad 3.38$

- $\quad 3.29 ; 3.38$

- $\quad 3.10 ; 3.12 ; 3.26 ; 3.29 ; 3.38 ; 3.45$ 
105 Gyrophaena strictula Erichson, 1839

106 Gyrophaena boleti (Linnaeus, 1758)

107 Gyrophaena transversalis Strand, 1939

108 Gyrophaena obsoleta Ganglbauer, 1895

109 Gyrophaena lucidula Erichson, 1837

110 Agaricochara latissima (Stephens, 1832)

111 Bolitochara obliqua Erichson, 1837

112 Bolitochara mulsanti Sharp, 1875

113 Bolitochara pulchra (Gravenhorst, 1806)

114 Bolitochara lucida (Gravenhorst, 1802)

115 Phymatura brevicollis (Kraatz, 1856)

116 Leptusa pulchella (Mannerheim, 1830)

117 Euryusa castanoptera Kraatz, 1856

118 Homalota plana (Gyllenhal, 1810)

119 Cyphea curtula (Erichson, 1837)

120 Placusa tachyporoides (Waltl, 1838)

121 Autalia longicornis Scheerpeltz, 1947

122 Oligota granaria Erichson, 1837

Hydrophilidae Latreille, 1802

123 Cercyon lateralis (Marsham, 1802)

124 Cercyon impressus (Sturm, 1807)

125 Megasternum obscurum (Marsham, 1802)

126 Cryptopleurum minutum (Fabricius, 1775)

Histeridae Gyllenhall, 1808

127 Gnathoncus buyssoni Auzat, 1917

Ptiliidae Heer, 1843

128 Nossidium pilosellum (Marsham, 1802)

Scarabaeidae Latreille, 1802

129 Geotrupes stercorosus (Scriba, 1791)

Scirtidae Fleming, 1821

130 Cyphon pubescens (Fabricius, 1792)

Elateridae Leach, 1815

131 Denticollis linearis (Linnaeus, 1758)

Dermestidae Latreillle, 1804

132 Globicornis emarginata (Gyllenhall, 1808)

Anobiidae Fleming, 1821

133 Dorcatoma flavicornis (Fabricius, 1792)

134 Dorcatoma substriata Hummel, 1829

135 Dorcatoma punctulata Mulsant et Rey, 1864

136 Dorcatoma dresdensis Herbst, 1792

137 Dorcatoma robusta Strand, 1938

138 Dorcatoma lomnickii Reitter, 1903

139 Dorcatoma chrysomelina Sturm, 1837

Trogossitidae Latreille, 1802

140 Peltis grossa (Linnaeus, 1758)

141 Ostoma ferruginea (Linnaeus, 1758)

142 Thymalus oblongus Reitter, 1889

143 Grynocharis oblonga (Linnaeus, 1758)

Cleridae Latreille, 1802

144 Tillus elongatus (Linnaeus, 1758)

145 Korynetes caeruleus (De Geer, 1775)

Nitidulidae Latreille, 1802

146 Epuraea distincta (Grimmer, 1841)

147 Epuraea biguttata (Thunberg, 1784)

148 Epuraea variegata (Herbst, 1793)

149 Epuraea silacea (Herbst, 1784)

150 Epuraea contractula J. Sahlberg, 1889

151 Epuraea concurrens Sjöberg, 1939

152 Epuraea limbata (Fabricius, 1787)

153 Epuraea unicolor (Olivier, 1790)

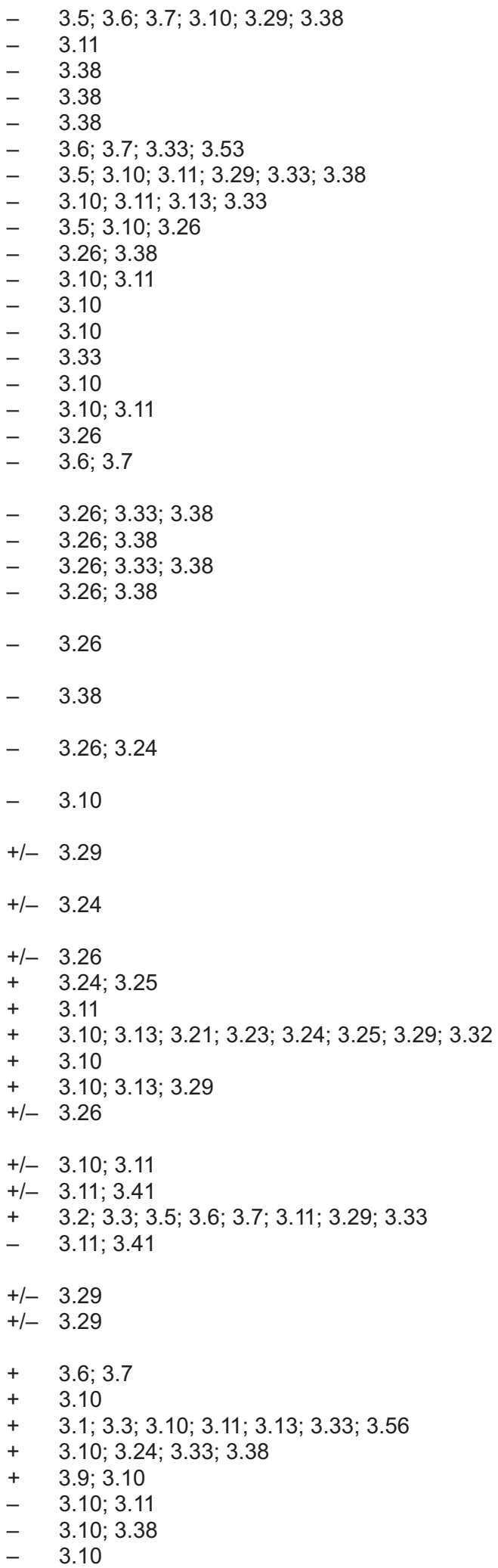


154 Pocadius ferrugineus (Fabricius, 1775)

155 Cyllodes ater (Herbst, 1792)

156 Glischrochilus grandis (Tournier, 1785) (= Glischrochilus grandis (Reitter, 1883))

157 Glischrochilus hortensis (Geoffroy, 1785)

Monotomidae Laporte de Castelnau, 1840

158 Rhizophagus bipustulatus (Fabricius, 1792)

159 Rhizophagus dispar (Paykull, 1800)

160 Rhizophagus parvulus (Paykull, 1800)

Sphindidae Jacquelin du Val, 1860

161 Aspidiphorus orbiculatus (Gyllenhal, 1808)

Cryptophagidae Kirby, 1837

162 Pteryngium crenatum (Fabricius, 1798)

163 Cryptophagus abietis (Paykull, 1798)

164 Cryptophagus acutangulus Gyllenhal, 1827

165 Cryptophagus badius Sturm, 1845

166 Cryptophagus saginatus Sturm, 1845

167 Cryptophagus dentatus (Herbst, 1793)

168 Cryptophagus pseudodentatus Bruce, 1934

169 Cryptophagus pubescens Sturm, 1845

170 Cryptophagus scanicus (Linnaeus, 1758)

171 Cryptophagus pallidus Sturm, 1845

172 Cryptophagus setulosus Sturm, 1845

173 Caenoscelis ferruginea (Sahlberg, 1820)

174 Atomaria pusilla (Paykull, 1798)

175 Atomaria fuscata (Schönherr, 1808)

176 Atomaria apicalis Erichson, 1846

177 Atomaria alpina Heer, 1841

178 Atomaria affinis (F. Sahlberg, 1834)

Erotylidae Latreille, 1802

179 Tritoma bipustulata Fabricius, 1775

180 Tritoma subbasalis (Reitter, 1896)

181 Triplax russica (Linnaeus, 1758)

182 Dacne bipustulata (Thunberg, 1781)

Cerylonidae Billberg, 1820

183 Cerylon fagi Brisout de Barneville, 1867

184 Cerylon histeroides (Fabricius, 1792)

185 Cerylon ferrugineum Stephens, 1830

186 Cerylon deplanatum Gyllenhal, 1827

Endomychidae Leach, 1815

187 Leiestes seminigra (Gyllenhall, 1808)

Corylophidae LeConte, 1852

188 Sericoderus lateralis (Gyllenhal, 1827)

189 Orthoperus rogeri Kraatz, 1874

(= Orthoperus punctulatus Reitter, 1876)

190 Orthoperus atomus (Gyllenhal, 1808)

191 Orthoperus corticalis (Redtenbacher, 1849) (= Orthoperus improvisus Bruce, 1946)

Latridiidae Erichson, 1842

192 Latridius hirtus Gyllenhal, 1827

193 Latridius consimilis Mannerheim, 1844

194 Latridius minutus (Linnaeus, 1767)

195 Latridius brevicollis (Thomson, 1868)

196 Enicmus fungicola Thomson, 1868

197 Enicmus rugosus (Herbst, 1793)

198 Dienerella filum (Aubé, 1850)

199 Corticaria impressa (Olivier, 1790)

200 Corticaria lapponica (Zetterstedt, 1838)
- $\quad 3.10 ; 3.11 ; 3.26 ; 3.38$

- $\quad 3.8 ; 3.10 ; 3.11 ; 3.24 ; 3.33$

- $\quad 3.10$

- $\quad 3.10 ; 3.38$

- $\quad 3.10$

$-\quad 3.10$

$-\quad 3.10$

$-\quad 3.10$

$-\quad 3.11 ; 3.38$

- $\quad 3.9 ; 3.57$

- $\quad 3.38$

$-\quad 3.4$

- $\quad 3.38$

- $\quad 3.23 ; 3.25 ; 3.26 ; 3.33 ; 3.38$

$-\quad 3.29$

- $\quad 3.9$

- $\quad 3.26 ; 3.38$

- $\quad 3.33$

- $\quad 3.10 ; 3.26 ; 3.38$

$-\quad 3.33$

$-\quad 3.38$

$-\quad 3.33$

- $\quad 3.13 ; 3.26 ; 3.38$

- $\quad 3.10 ; 3.11 ; 3.29$

$+\quad 3.41$

$+\quad 3.12 ; 3.35 ; 3.49 ; 3.51$

$+\quad 3.6 ; 3.7 ; 3.21 ; 3.27 ; 3.34 ; 3.49 ; 3.50$; $3.51 ; 3.53$

$+\quad 3.10 ; 3.24 ; 3.26 ; 3.38$

$+\quad 3.2 ; 3.6 ; 3.7 ; 3.9 ; 3.12 ; 3.23 ; 3.25 ; 3.26 ; 3.33$;

$3.38 ; 3.47 ; 3.49 ; 3.53$

- $\quad 3.13 ; 3.21 ; 3.38$

- $\quad 3.6 ; 3.7 ; 3.10 ; 3.27$

- $\quad 3.3 ; 3.10 ; 3.13$

- $\quad 3.2 ; 3.10 ; 3.27$

+/- 3.10; 3.33

- $\quad 3.38$

$-\quad 3.2$
$-\quad 1.38$

- $\quad 3.26$

- $\quad 3.4 ; 3.10 ; 3.26 ; 3.38$

- $\quad 3.10 ; 3.27 ; 3.51$

- $\quad 3.10 ; 3.27 ; 3.33$

- $\quad 3.4 ; 3.10$

- $\quad 3.10$

- 3.10

- $\quad 3.10$

- $\quad 3.6 ; 3.7 ; 3.10$

- $\quad 3.10$

- $\quad 3.10$ 
201 Corticaria serrata (Paykull, 1798)

202 Corticaria rubripes Mannerheim, 1844

203 Corticaria alleni Johnson, 1974

204 Corticaria longicollis (Zetterstedt, 1838)

205 Corticaria elongata (Gyllenhal, 1827)

206 Cortinicara gibbosa (Herbst, 1793)

Ciidae Leach, 1819

207 Cis lineatocribratus Mellié, 1848

208 Cis alter Silfverberg 1991

(= Cis nitidus auct. nec (Fabricius 1792))

209 Cis glabratus Mellié, 1848

210 Cis jacquemartii Mellié, 1848

211 Cis comptus Gyllenhal, 1827

212 Cis hispidus (Paykull, 1798)

213 Cis micans (Fabricius, 1792)

214 Cis boleti (Scopoli, 1763)

215 Cis rugulosus Mellié, 1848

216 Cis punctulatus Gyllenhal, 1827

217 Cis fissicornis Mellié, 1848

218 Cis bidentatus (Olivier, 1790)

219 Ennearthron cornutum (Gyllenhal, 1827)

220 Ennearthron laricinum (Mellié, 1848)

221 Ennearthron palmi Lohse, 1966

222 Sulcacis bidentulus (Rosenhauer, 1847)

223 Sulcacis affinis (Gyllenhal, 1827)

224 Sulcacis fronticornis (Panzer, 1809)

225 Wagaicis wagai (Wankowicz, 1869)

226 Ropalodontus strandi (Lohse, 1969) *

227 Octotemnus glabriculus (Gyllenhal, 1827)

Colydiidae Erichson, 1842

228 Bitoma crenata (Fabricius, 1775)

Mycetophagidae Leach, 1815

229 Triphyllus bicolor (Fabricius, 1777)

230 Litargus connexus (Geoffroy, 1785)

231 Mycetophagus quadripustulatus (Linnaeus, 1761) +

232 Mycetophagus piceus (Fabricius, 1777)

233 Mycetophagus ater (Reitter, 1879)

234 Mycetophagus decempunctatus Fabricius, 1801

235 Mycetophagus multipunctatus Fabricius, 1792

236 Mycetophagus quadriguttatus Müller, 1821

Tetratomidae Billberg, 1820

237 Tetratoma ancora Fabricius, 1790

238 Hallomenus axillaris (Illiger, 1807)

239 Hallomenus binotatus (Quensel, 1790)

Melandryidae Leach, 1815

240 Orchesia micans (Panzer, 1794)

241 Orchesia fasciata (Illiger, 1798)

242 Orchesia fusiformis Solsky, 1871

243 Abdera affinis (Paykull, 1799)

244 Abdera flexuosa (Paykull, 1799)

245 Wanachia triguttata (Gyllenhal, 1810) $-\quad 3.27$

$-\quad 3.10$

$-\quad 3.26$

- $\quad 3.4 ; 3.23$

$-\quad 3.10$

$-\quad 3.10$

$+\quad 3.10 ; 3.19 ; 3.29 ; 3.33$

$+\quad 3.10 ; 3.11 ; 3.13 ; 3.26$

$+\quad 3.10 ; 3.11 ; 3.25 ; 3.31 ; 3.33 ; 3.53$

$+\quad 3.10 ; 3.11 ; 3.13 ; 3.28 ; 3.29 ; 3.32 ; 3.33 ; 3.56$

+ $\quad 3.2 ; 3.3 ; 3.4 ; 3.6 ; 3.7 ; 3.12 ; 3.13 ; 3.20 ;$

$3.27 ; 3.48 ; 3.49 ; 3.50 ; 3.51 ; 3.52 ; 3.56$

+ $\quad 3.3 ; 3.23 ; 3.27 ; 3.47 ; 3.49 ; 3.50 ; 3.51$; $3.52 ; 3.53$

$+\quad 3.3 ; 3.27 ; 3.46 ; 3.49 ; 3.50 ; 3.52 ; 3.53$

+ $\quad 3.6 ; 3.7 ; 3.27 ; 3.47 ; 3.49 ; 3.50 ; 3.51 ; 3.52$ 3.53

$+\quad 3.27 ; 3.48$

$+\quad 3.54 ; 3.55 ; 3.56$

$+\quad 3.27 ; 3.49 ; 3.50 ; 3.51 ; 3.52 ; 3.53$

$+\quad 3.26$

$+\quad 3.4 ; 3.6 ; 3.7 ; 3.8 ; 3.10 ; 3.11 ; 3.12 ; 3.13$ $3.21 ; 3.23 ; 3.24 ; 3.25 ; 3.26 ; 3.28 ; 3.29$;

$3.31,3.32 ; 3.33 ; 3.41 ; 3.56$

$+\quad 3.4 ; 3.11 ; 3.12 ; 3.26 ; 3.33 ; 3.51$

$+/-3.26$

$+\quad 3.12 ; 3.37 ; 3.47$

+ $\quad 3.2 ; 3.3 ; 3.12 ; 3.18 ; 3.27 ; 3.33 ; 3.42 ; 3.48$; $3.49 ; 3.50 ; 3.51 ; 3.53$

+ $\quad 3.2 ; 3.3 ; 3.6 ; 3.7 ; 3.25 ; 3.26 ; 3.28 ; 3.48 ; 3.49$; $3.50 ; 3.51 ; 3.53$

$+\quad 3.27 ; 3.49 ; 3.50 ; 3.51 ; 3.53$

$+\quad 3.10 ; 3.56$

$+\quad 3.12 ; 3.27 ; 3.48 ; 3.50 ; 3.51 ; 3.53$

$-\quad 3.10 ; 3.50$

$+\quad 3.9 ; 3.33$

$+\quad 3.6 ; 3.7 ; 3.10 ; 3.33 ; 3.38$

$3.2 ; 3.24 ; 3.26 ; 3.33 ; 3.38$

$3.2 ; 3.6 ; 3.7 ; 3.10 ; 3.13 ; 3.21 ; 3.23 ; 3.24$;

$3.25 ; 3.26 ; 3.33 ; 3.38$

+ $\quad 3.2 ; 3.6 ; 3.7 ; 3.10 ; 3.11 ; 3.24 ; 3.26 ; 3.33$ 3.38

$+$

$3.10 ; 3.13 ; 3.24 ; 3.25 ; 3.26 ; 3.33 ; 3.38$

$+\quad 3.4 ; 3.25 ; 3.26 ; 3.33 ; 3.38$

$-\quad 3.26$

- $\quad 3.2 ; 3.10 ; 3.32 ; 3.33$

$+\quad 3.18 ; 3.26 ; 3.38 ; 3.40 ; 3.41 ; 3.57$

$+\quad 3.18 ; 3.26 ; 3.39 ; 3.40 ; 3.41 ; 3.42 ; 3.57$

$+\quad 3.10 ; 3.21 ; 3.23 ; 3.24 ; 3.25 ; 3.27 ; 3.29$

+ +- 3.18; 3.26

$+\quad 3.25 ; 3.27 ; 3.49 ; 3.50 ; 3.51 ; 3.53$

$+\quad 3.24 ; 3.25 ; 3.29 ; 3.51 ; 3.53$

$+\quad 3.25 ; 3.51$

$+\quad 3.54 ; 3.55$ 
246 Zilora elongata J. Sahlberg, 1881

247 Melandrya dubia (Schaller, 1783)

248 Phryganophilus auritus Motschulsky, 1845

Anaspidae Mulsant, 1856

249 Anaspis marginicollis Lindberg, 1925

250 Anaspis arctica Zetterstedt, 1828

Mordellidae Latreille, 1802

251 Tomoxia bucephala Costa, 1854

252 Variimorda villosa (Schrank, 1781)

253 Curtimorda maculosa (Naezen, 1794)

254 Curtimorda bisignata (Redtenbacher, 1849)

Tenebrionidae Latreille, 1802

255 Bolitophagus reticulatus (Linnaeus, 1767)

256 Eledona agaricola (Herbst, 1783)

257 Diaperis boleti (Linnaeus, 1758)

258 Neomida haemorrhoidalis (Fabricius, 1787)

259 Scaphidema metallicum (Fabricius, 1792)

260 Pentaphyllus testaceus (Hellwig, 1792)

261 Upis ceramboides (Linnaeus, 1758) $+\quad 3.54 ; 3.55$

$+/-3.10 ; 3.29$

$+/-3.20$

$+\quad 3.23$

$+\quad 3.32$

$+/-\quad 3.10 ; 3.29$

$+/-3.10$

$+\quad 3.14 ; 3.15 ; 3.16$

$+\quad 3.14 ; 3.15 ; 3.16 ; 3.17$

$+\quad 3.10 ; 3.29$

$+\quad 3.26$

$+\quad 3.4 ; 3.11 ; 3.26 ; 3.33 ; 3.28$

$+\quad 3.10 ; 3.13$

$-\quad 3.3$

$+\quad 3.26 ; 3.38$

$+/-3.10 ; 3.33$

*) For the European Russia, R. perforatus (Gyllenhal, 1813) has previously been reported instead of the rather recently described $R$. strandi. Our studies show that the Ropladontus species distributed in the north- and middle-European Russia (including Moscow region), and also in Siberia and Rus sian Far East, is R. strandi Lohse, 1969. Of two syntypes of Cis perforatus Gyllenhal, 1813 (= Ropalodontus perforatus (Gyllenhal, 1813)) 1 male Nr. 1281b was selected as a lectotype. We studied also Ropalodontus strandi Lohse, 1969 male paratype labelled "Nordreisa Bilto, Strand". The comparison of Ropalodontus specimens collected in Moscow region and other regions of European Russia and Siberia with types revealed their identity with the type of Ropalodontus strandi Lohse, 1969 and differences from R. perforatus. The last species is recorded for the territory of former USSR only for Carpathian Mountains. 